\title{
Irrigated common bean (Phaseolus vulgaris L.) performance on calcareous alkaline soils as influenced by previous crops in North of Sudan
}

\author{
Abdelazim Mohammed Ali * \\ Department of Horticulture, Faculty of Agriculture, Nile Valley University, Atbara, Sudan
}

\section{Article Info}

Received : 22.08 .2017

Accepted : 27.05.2018

\begin{abstract}
This study examines the ability of different cropping sequence (including or not including alfalfa) to improve bean productivity in calcareous and alkaline soils of the old Nile (high) terraces in North of Sudan. The soil in the experimental site is sandy clay to sandy clay loom. Soil properties were examined before planting and after bean harvest. Salinity which was greater in non-reclaimed soil decreased regardless of the cropping sequence. Soil alkalinity remain higher than 8 in all cropping sequence after more than 6-7 cropping seasons. P (Olsen) and calcium carbonate showed inconsistent trends regardless of the cropping sequence. Organic carbon increased after bean cultivation in both cropping sequence. Change in growth parameters as affected by cropping sequence were significant in various levels, however, that determining yield were not. Presence of alfalfa in the cropping sequence increased seed yield, number of pods per plant, number of seeds per pods, pod length, plant length, leaf length, leaf width, fresh plant weight, nodule number. However seed weight was decreased.
\end{abstract}

Keywords: Alfalfa, calcareous soils, common bean, cropping sequence, Sudan.

(C) 2018 Federation of Eurasian Soil Science Societies. All rights reserved

\section{Introduction}

Common bean (Phaseolus vulgaris $L$ ) is one of the most favorable grain legumes valued for its nutritional value, especially its high protein content (20-25\%). The crop also has the ability to maintain soil fertility through biological nitrogen fixation, and thus may be required to maintain soil productivity.

In Northern Sudan Common bean is conventionally competing for areas where fertile soils of the recent terrace of the Nile alluvial are available. It mostly grown under pump irrigation or river flood recession areas during the winter season. The limited areas of these types of soils can no longer being available to satisfy the increasing domestic demand for cool season legumes including common bean. Most soil resources in Northern states of Sudan are available in the old Nile (high) terraces. As desert soils, they exhibit low nutrient levels with a high trend of nutrient deficiency due to their fragile nature (Elhagwa, 2011). Newly reclaimed desert soils exist in Northern Sudan are usually sandy or calcareous in nature or, some time, saline-sodic when there is high content of reactive clays. In both cases, it exhibits high $\mathrm{pH}$ values (Elhagwa et al., 2007; Ibrahim et al., 2013) .

Calcareous soils are common in arid and semi-arid climates affecting over 1.5 billion acres of soil worldwide. Calcareous soils are identified by the presence of the mineral calcium carbonate $\left(\mathrm{CaCO}_{3}\right.$ or lime $)$. The $\mathrm{pH}$ of these soils is usually above 7 and may be as high as 8.5 (Ceyhan et al., 2014). When these soils contain sodium carbonate, the $\mathrm{pH}$ may exceed 9 . Yet these types of soils can be extremely productive for agricultural use when they are managed properly. Limited availability of phosphorus and micronutrient are often the most limiting factor for plant growth in alkaline and calcareous soils. A series of fixation reactions occur that

\footnotetext{
${ }^{*}$ Corresponding author.

Department of Horticulture, Faculty of Agriculture, Nile Valley University, Atbara, Sudan

Tel.: + 249122161416

e-ISSN: 2147-4249
}

E-mail address: azimali58@yahoo.com DOI: $10.18393 /$ ejss.435073 
gradually decrease the solubility and availability of these nutrients to plants even if applied to the soil in solvable forms (Leytem and Mikkelsen, 2005).

Inoculation of legume crops with nitrogen-fixing soil bacteria, collectively known as rhizobia, has been widely used to improve legume productivity in fields. Problems of establishment of the introduced inoculants were frequently encountered by several edaphic factors, such as soil chemical and physical conditions. However, improvement of biological $\mathrm{N}$ fixation is widely reported by decreasing soil alkalinity and improvement of P availability (Attar et al., 2012).

Michiels et al. (1998) investigated the symbiotic relationship between common bean and approximately 100 tropical rhizobium strains in Amazon region. More than $90 \%$ of the strains tested induced nodules or nodule-like structures on the bean cultivar, $32 \%$ of which reduced atmospheric nitrogen. These results deny the assumption that common bean bears a poor symbiotic relationship with rhizobia, and confirm the other that it is a non-selective host for nodulation.

Alfalfa is a widely grown fodder legume known to perform well on recently reclaimed calcareous soils and have the ability of nitrogen fixation and removing of high amounts of calcium from calcareous soils, It usually remain for more than three years as productive fodder crop. It is roots and litter residues usually recommended to improve soil chemical and physical properties. This study was conducted to investigate alfalfa effect on soil properties as a soil reclamation crop and common bean performance as a subsequent crop.

\section{Material and Methods}

\section{Experimental site and design}

An on field experiment was conducted at food security scheme, Ed Damer in River Nile State, Sudan during $2015 / 16$ and $2016 / 17$ winter seasons. The field is situated at $17^{\circ} 32^{\prime} \mathrm{N}$ latitude and $33^{\circ} 59^{\prime} \mathrm{E}$ longitude. The climate of the area is an arid to marginal semiarid. The present investigation was carried out on desert moderately calcareous loamy soil classified as Aridisol (Buursink, 1971) which is usually found in the new agricultural fields of third (high) terrace of the Nile. Seeds of local popular cultivar Berber of Phaseolus vulgaris (L) were sown on the first week of November on $70 \mathrm{~cm}$ ridges and $20 \mathrm{~cm}$ within row spacing. Two seeds were sown per hole. Experiment was laid out in randomized complete block design with three replications with larger plot size $6 \mathrm{X7} \mathrm{m}$ to represent similar farmer conditions. Di-ammonium phosphate fertilizer was added as starter doze at rate of $100 \mathrm{Kg} / \mathrm{ha}$. Pendamate and Persuit (pendimethalin and imazythapyr) were sprayed before watering for control of both broad leafed and monocot weeds as recommended.

The experiment treatments was laid out as indicated in Table 1.

Table 1. The experiment treatments

\begin{tabular}{cc}
\hline Treatments & Cropped bean plots \\
\hline $\mathrm{T}_{1}$ & On reclaimed soil with crops including alfalfa \\
$\mathrm{T}_{2}$ & On reclaimed soil with crops not including alfalfa \\
\hline
\end{tabular}

\section{Analysis of soil properties}

The soil in the experimental site was sandy clay to sandy clay loom. Soil samples were collected from 0-20 $\mathrm{cm}$ depth in two different periods: initial (before bean cultivation) and final (after bean harvesting in the first season) from three sites representing non reclaimed soil, reclaimed and cropped soil with crops not including alfalfa and reclaimed soil with crops including alfalfa.

Available soil phosphorus was extracted with $\mathrm{NaHCO}_{3}$ then acidified and determined calorimetrically after treating with ammonium molybdate at a wavelength of $660 \mathrm{~nm}$, according to Olsen method by PG - T 60 spectrophotometer (UK) adapted by Patel and Ladawala (2013). Some of the physical and chemical characteristics of the soil at the experimental site shown in Table 2 were analyzed as indicated by Estefan et al. (2014).

\section{Measurement of growth and yield parameters}

Ten plants were randomly selected for the measurement of various morphological growth parameters (shoot length, leaf width and length, number of root nodules, root and shoot dry weight) and yield parameters (pod length, number of seeds/pod, number of pods/plant and 1000 seed weight) were determined at and after harvest. The results were statistically analyzed using Analysis of Variance and means were separated with LSD using the computer program SAS (2003). 


\section{Results and Discussion}

Analysis of soil revealed slight change in soil properties with various cropping system of soil reclamation. As indicated in Table 2 salinity which was greater in non-reclaimed soil ( $\left.1.5 \mathrm{~d} \mathrm{Sm}^{-1}\right)$ was decreased to $(0.2-0.4$ $\mathrm{d} \mathrm{Sm}^{-1}$ ) regardless of the cropping sequence. Soil alkalinity expressed as pH range was 9.23 in nonreclaimed soil and remain higher than 8 in all cropping sequence after more than 6-7 cropping seasons, although both $\mathrm{Na}$ and SAR within non harmful range. The relationship between $\mathrm{P}$ (Olsen) and calcium carbonate showed inconsistent trends as both of them were high in non-reclaimed soil sample, however, $\mathrm{P}$ showed higher levels and calcium carbonate showed moderate levels in cropping sequence with alfalfa before bean cultivation and $\mathrm{P}$ with low levels and carbonate different levels before and after bean cultivation in cropping system with no alfalfa.

Table 2. Soil analysis

\begin{tabular}{|c|c|c|c|c|c|c|c|c|c|c|c|c|}
\hline & $\mathrm{pH}$ & $\begin{array}{l}\text { EC, } \\
\mathrm{dSm}^{-1}\end{array}$ & $\begin{array}{c}\mathrm{CaCO}_{3}, \\
\%\end{array}$ & $\begin{array}{l}\mathrm{Na}, \\
\mathrm{Mmol}^{-L^{-1}}\end{array}$ & SAR & $\begin{array}{c}\text { Sol. K, } \\
\text { mmol L }^{-1}\end{array}$ & $\begin{array}{l}\text { Olsen-P, } \\
\text { mg kg- }^{-1}\end{array}$ & $\begin{array}{l}\text { Org.C, } \\
\%\end{array}$ & $\begin{array}{l}\text { Sand, } \\
\%\end{array}$ & $\begin{array}{l}\text { Silt, } \\
\%\end{array}$ & $\begin{array}{l}\text { Clay, } \\
\%\end{array}$ & $\begin{array}{l}\text { Textural } \\
\text { Class }\end{array}$ \\
\hline 1 & 9.23 & 1.5 & 10.3 & 0.05 & 0.018 & 0.03 & 20 & 0.25 & 56 & 10 & 34 & SCL \\
\hline 2 & 8.01 & 0.4 & 8.4 & 0.02 & 0.009 & 0.03 & 5 & 0.68 & 52 & 14 & 34 & SCL \\
\hline 3 & 8.11 & 0.2 & 8.7 & 0.02 & 0.009 & 0.03 & 8 & 0.75 & 49 & 14 & 37 & SC \\
\hline 4 & 8.07 & 0.9 & 8.4 & 0.05 & 0.016 & 0.03 & 19 & 0.40 & 47 & 8 & 45 & SC \\
\hline 5 & 8.13 & 0.8 & 10.9 & 0.05 & 0.015 & 0.03 & 5 & 0.40 & 52 & 14 & 34 & SCL \\
\hline
\end{tabular}

1 - Non reclaimed soil

2- Three seasons wheat, 3 years alfalfa, one season fodder sorghum, soil sample taken after growing common bean

3-Three seasons wheat, one season fodder sorghum, one season tomato, one season faba bean, one season fodder sorghum, soil sample taken after growing common bean

4- Three seasons wheat, 3 years alfalfa, one season fodder sorghum, soil sample taken before growing common bean

5-Three seasons wheat, one season fodder sorghum, one season tomato, one season faba bean, one season fodder sorghum, soil sample taken before growing common bean

Organic carbon revealed higher values after bean cultivation in both cropping sequence $\left(\mathrm{T}_{1}\right.$ and $\left.\mathrm{T}_{2}\right)$ compared to other sampled soils. Observation of growth and yield parameters revealed that absence of alfalfa from the cropping sequence reduced yield, number of pods per plant, number of seed per pods, pod length, plant length, leaf length, leaf width, fresh plant weight and nodule number. Seed weight (1000 seed weight) were greater where alfalfa was absent from the cropping sequence (Table 3 and 4). The effect on growth parameters was significant in various levels with the exception of leaf width in the first season, however, it was not significant in yield parameters with the exception of pod length in both seasons and seeds /pod in the first season.

Table 3. Performance of common bean (Phaseolus Vulgaris L.) yield and yield components under different soil reclamation means using different cropping sequence over two seasons

\begin{tabular}{lllllllllll}
\hline \multirow{2}{*}{ Treatments } & \multicolumn{2}{c}{ Yield, kg/ ha } & \multicolumn{2}{c}{ 1000 seed weight, g } & \multicolumn{2}{c}{ Pods/ plant } & \multicolumn{2}{c}{ Seeds/ pod } & \multicolumn{2}{c}{ Pod length, cm } \\
\cline { 2 - 11 } & $2015 / 16$ & $2016 / 17$ & $2015 / 16$ & $2016 / 17$ & $2015 / 16$ & $2016 / 17$ & $2015 / 16$ & $2016 / 17$ & $2015 / 16$ & $2016 / 17$ \\
\hline T1 & 1801 & 1330.7 & 301.7 & 304.7 & 26 & 19 & 6.1 & 9.3 & 9.17 & 9.3 \\
T2 & 1598 & 1262.0 & 310.7 & 301.3 & 24 & 17.7 & 5.94 & 8.4 & 7.8 & 8.4 \\
Mean & 1699.5 & 1296.4 & 306.2 & 303 & 25 & 18.4 & 6 & 8.9 & 8.5 & 8.9 \\
Cv \% & 2.01 & 5.6 & 14.2 & 1.4 & 4.90 & 23.6 & .68 & 1.4 & 3.37 & 1.4 \\
Sig. level & NS & NS & NS & NS & NS & NS & NS & $*$ & $*$ & $*$ \\
LSD & 847.8 & 255.7 & 21.7 & 14.34 & 4.3 & 15.5 & .15 & 0.43 & 1.004 & 0.43 \\
\hline
\end{tabular}

T1 On reclaimed soil with crops including alfalfa

T2 On reclaimed soil with crops not including alfalfa

Table 4. Common bean (Phaseolus Vulgaris L.) growth parameters performance under different soil reclamation means using different cropping sequence

\begin{tabular}{lllllllllll}
\hline \multirow{2}{*}{ Treatments } & \multicolumn{2}{c}{ Plant length, cm } & \multicolumn{2}{l}{ Leaf length, cm } & \multicolumn{2}{c}{ Leaf width, cm } & \multicolumn{2}{l}{ Fresh Plant weight,g } & \multicolumn{2}{c}{ Nodule No. } \\
& $2015 / 16$ & $2016 / 17$ & $2015 / 16$ & $2016 / 17$ & $2015 / 16$ & $2016 / 17$ & $2015 / 16$ & $2016 / 17$ & $2015 / 16$ & $2016 / 17$ \\
\hline T1 & 88 & 84.3 & 11.57 & 10.5 & 7.7 & 7.3 & 472 & 378 & 12.3 & 11.6 \\
T2 & 45.3 & 56 & 8.6 & 8.6 & 7.13 & 5.8 & 304 & 292.7 & 2.3 & 2 \\
Mean & 66.7 & 70.2 & 10.1 & 9.6 & 7.4 & 6.6 & 388 & 325.4 & 7.3 & 6.8 \\
Cv \% & 9.02 & 7.3 & 7.76 & 5.1 & 19.08 & 3.8 & 1.90 & 6.9 & 9.64 & 15.8 \\
Sig. level & $* *$ & $*$ & $*$ & $*$ & NS & $*$ & $* *$ & $*$ & $* *$ & $* *$ \\
\hline
\end{tabular}


Results from this study indicated substantial improvement in soil properties including soil reaction and salinity after applying amendment treatments. The added organic mulch biomass from the different crop residues likely led to enhanced nutrient mineralization and subsequent uptake of nutrients by the growing bean crop. However, the relationship between biomass production and seed yield was not consistent, as good growth obtained by $\mathrm{T}_{1}$ dos not reflected in similar significant seed yield increase by $\mathrm{T}_{2}$ treatment. Although biomass production is closely related to yield, this relationship may be difficult to establish in legumes including bean. This suggest that reduced above ground growth in $\mathrm{T}_{2}$ bean treatment mean that larger amount of assimilates were directed to seed production and although pod number and length is rather smaller, seed weight was rather greater compensating some of yield difference.

Vargas and Graham (1988) found a large variation in the number of nodules on bean roots and reported that this was mostly dependent on the genotype. They observed that the number of nodules ranged from 0 to 190 per plant. Increased number of root nodules in $\mathrm{T}_{1}$ treatment, suggested that alfalfa as soil amendments for bean cultivation is of comparative advantage in establishment of nitrogen-fixing bacteria in bean cultivation leading to an improved soil physical and chemical environment for rhizobium activity.

\section{Conclusion}

In calcareous and alkaline soils, phosphorus and micronutrients unavailability usually affect negatively bean productivity. Cropping systems is particularly good mean for desert soil reclamation, it can be used for improving soil for maximum crop productivity with minimal financial and environmental cost in comparison to chemical reclamation means. The relatively higher productivity by the cropping sequence including alfalfa treatment may be due to the improvement of physical, chemical and biological properties of the soil.

\section{References}

Attar, H.A., Blavet, D., Selim, E.M., Abdelhamid, M.T., Drevon, J.J., 2012. Relationship between phosphorus status and nitrogen fixation by common beans (Phaseolus vulgaris L.) under drip irrigation. International Journal of Environmental Science and Technology 9(1): 1-13.

Buursink, J., 1971. Soils of central Sudan. Grafisch Bedrijf Schotanus \& Jens Utrecht N.V. 248p.

Ceyhan, E., Kahraman, A., Avci, M.A., Dalgic, H., 2014. Combining ability of bean genotypes estimated by line x tester analysis under highly-calcareous soils. The Journal of Animal \& Plant Sciences 24(2): 579-584.

Elhagwa, A, Richter, C., Gedamu, A., 2007. Properties of new reclaimed soils in the Merowi irrigation project of North Sudan. Journal of Agriculture and Rural Development in the Tropics and Subtropics 108(2): 113-121.

Elhagwa, A., 2010. Climatic variation and its effect on general properties of soils of Sudan. The Fourth International Conference on Agriculture and Rural Development. Saudi Society for Agricultural Sciences. Faculty of Science of Food and Agriculture, King Saud University, 4-7 April 2011, Hail, Saudi Arabia [in Arabic].

Estefan, G., Sommer, R., Ryan, J., 2014. Analytical methods for soil-plant and water in the dry areas. A Manual of Relevance to the West Asia and North Africa Region. $3^{\text {rd }}$ Edition, International Center for Agricultural Research in the Dry Areas, Aleppo, 255 p.

Ibrahim, M.M.M., Dafalla, M.S., Elhag, A.M.H, Ibrahim, I.S., 2013. Monitoring, predicting and quantifying soil salinity, sodicity and alkalinity in Sudan, using soil techniques, remote sensing and GIS Analysis, Case study: University of Khartoum top farm. International Journal of Scientific and Research Publications 3(3): 1-7.

Leytem, A.B., Mikkelsen, R.L., 2005. The nature of phosphorus in calcareous soils. Better Crops 89 (2): 11-13. Available at [access date: 23.08.2017]: https://eprints.nwisrl.ars.usda.gov/14/1/1159.pdf

Michiels, J., Dombrecht, B., Vermeiren, N., Xi, C., Luyten, E., Vanderleyden, J., 1998. Phaseolus vulgaris is a non-selective host for nodulation. FEMS Microbiology Ecology 26(3): 193-205.

Patel, D.H., Milan, M., 2013. Study of presence of available phosphorus in soil of Kalol-Godhra taluka territory. Archives of Applied Science Research 5(4): 24-29.

SAS Institute Inc. 2003. SAS/STAT User's Guide, Version 9.1.

Vargas, A.A.T., Graham, P.H., 1988. Phaseolus vulgaris cultivar and Rhizobium strain variation in acid-pH tolerance and nodulation under acid conditions. Field Crops Research 19: 91-101. 